\title{
Should Iraq Adopt IFRSs?
}

\author{
Mohammad Abud-Allah Ibrahim, Patricia Stanton, and Marcus Rodrigs
}

\begin{abstract}
Over the two past decades, the rapid integration of capital markets underlined the necessity for developing a single set of high quality international accounting standards. The growing acceptance of international accounting standards has given power for International Accounting Standards Board (IASB) to work and develop this project. Iraq is a country where its accounting practices have been influenced by different philosophies from outside and inside Iraq during its modern history. After the fall of Saddam Hussain international institutions have begun to play an important role in reshaping Iraq's economy including its accounting for oil. This paper investigates the challenges and opportunities for Iraq in transitioning from its national Unified Accounting System (UAS) to International Financial Reporting Standards (IFRSs). The investigation used a qualitative research approach including two research methods. For archival resources to the accounting system and the pressure to change, content analysis was used. To ascertain the views of persons of significant importance, In-depth semi-structured interviews were conducted with academics, managers, consultants, CFO, CAO, and accounting professionals in Iraq based on the New Institutional Theory (Isomorphism) was used to analyze the interview transcripts. The results revealed that the current situation in Iraq is an example of institutional isomorphism, specifically coercive isomorphism by the World Bank and IMF; mimetic isomorphism by the IOCs and normative isomorphism by the Big 4 accounting firms. Further, this study highlights the need for further research into the impact of adopting IFRSs in developing and emerging countries, particularly those in the Middle East.
\end{abstract}

Index Terms-IFRS, institutional theory, accounting system, world bank, IMF, Big 4 accounting firms.

\section{INTRODUCTION}

Gray (1988) in a seminal paper reflected on how accounting procedures and policies are affected by a country's political environment. Iraq is one such country [1]. Its accounting practices have been influenced over by the years by the British, the Russian and Egyptian accounting systems [2] and more recently by the philosophy of the Arab Baath Socialist party that begin its rule in Iraq in 1968. The Arab Baath Socialist party, in line with its philosophy of control, initiated the Unified Accounting System (UAS).

Manuscript received June 5, 2014; revised August 16, 2014.

Mohammad Abud-Allah Ibrahim is with University of Baghdad and currently is with Newcastle Business School, Faculty of Business \& Law, The University of Newcastle Australia (e-mail: mohammed.ibrahim@uon.edu.au).

Patricia Stanton and Marcus Rodrigs are with Newcastle Business School, Faculty of Business \& Law, The University of Newcastle Australia (e-mail:

Marcus.Rodrigs@newcastle.edu.au).
This is the current system that Iraq still follows, reflecting the previous centralized regime's agenda. Although Iraq is changing, the changes come from external pressures, particularly from the developed countries those see business potential in Iraq. Along with the positive move to re-build Iraq, international institutions such as the World Bank, IMF, and Big 4 accounting firms are pushing Iraq to adopt International Financial Reporting Standards (IFRSs). Change to IFRSs has been widely advocated in the literature on the grounds that IFRSs may help countries such as Iraq to develop their economies by opening them to greater international trade and investment opportunities [3]. However, the assumption that better markets depend on better financial reporting is still poorly understood [4]. The literature on post IFRSs adoption is scant and the question as to whether the hypothesized advantages of adopting IFRSs have been achieved is debatable.

For Iraq to adopt the IFRSs is an enormous change as the UAS serves the interests of the central government; IFRSs do not. This change would impose great upheaval on the accounting practitioners who have no background in accounting standards other than the UAS. The training and related costs for such a change have been shown to be an obstacle to convergence with IFRSs in Europe where the choice was voluntary [5]. Informed by institutional theory [6] this paper critically reviews the arguments for Iraq to transition to IFRSs by examining the opportunities and challenges of Iraq's transitioning from its UAS to IFRSs, and evaluates whether the change will be beneficial to Iraq. While this study will focus on Iraq, it may also reflect the position of countries that have similar political and social environments. The findings may be applicable to similar countries in the Middle East such as Iran, Libya, Saudi Arabia, Egypt and Syria which face similar decisions whether to transition from their accounting systems to IFRSs or to continue with their own system.

Further, the study may also be useful for Multi-National Companies (MNCs) or International Oil Companies (IOCs) that are doing business or participating in Iraq's reconstruction and do not use the IFRSs as to whether they should also transition to IFRSs for their business operations and reporting in Iraq.

In March 2003, the USA and its allies invaded Iraq to topple Saddam's regime because they suspected the government of Iraq had banned weapons of war [7]. The invasion forced the Arab Ba'ath Party out of power and a new provisional government was established in 2003. The new government needed to reconstruct the immense damage caused by several wars to the infrastructure of the rich oil industry. Revenues from oil were seen to the best way to boost the economy as $95 \%$ of Iraq's foreign trade earnings come from oil [8]. 
After the fall of Saddam's regime in 2003, Iraq has seen dramatic economic changes. As mentioned earlier, with the support of the World Bank and the International Monetary Fund (IMF) Iraq appears to be moving from a central to a market economy. The key players with vital roles in the changing of the economy and its accounting systems in Iraq are the international institutions such as World Bank and IMF, the international oil and gas companies and the Big 4 Accounting firms and local Iraqi institutions such as the Board of Supreme Audit. Their roles are discussed in the following section.

Following the funding conditions of The World Bank and IMF, the Development Fund for Iraq (DFI) was established in 2003. The DFI's purpose is to ensure that the proceeds of Iraq's oil export sales and other frozen Iraqi funds should be used for the benefit of the Iraqi people [9]. In establishing the Fund, the World Bank and the IMF advised Iraq to consider changing its accounting system [10]. This advice is not unusual as the World Bank has pushed countries to adopt International Financial Reporting Standards (IFRSs), and at times makes the adoption of IFRSs as a requirement for its loans [11].

\section{BACKGROUND OF IRAQ AND ITS ACCOUNTING SYSTEM AFTER 2003}

\section{A. World Bank, IMF, IOCs, and Big 4 Accounting Firms}

After the fall of Saddam the Iraqi economy inherited a heavy legacy of imbalances and economic problems that reflected the destruction of infrastructure, along with debt of \$US127 billion. This debt is equivalent to $500 \%-600 \%$ of Iraq's GDP [12]. These issues forced Iraq to comply and work with the IMF, a supervisor of the Iraqi DFI. As a result, Iraq had to adopt the Convention on Emergency Post-Conflict Assistance (EPCA) between itself and the IMF. In September 2004, the IMF lent Iraq an amount of \$US297.1 million by way of Special Drawings Rights (SDRs). SDRS are available for member countries that need assistance in post-conflict emergency and/or to support the rebuilding of a country. Iraq requested financial support to enable the country to resolve its debt issues. The support of the IMF enabled Iraq to remove almost $80 \%$ of its debt and to reschedule the remaining portion for repayment [13], [14]. The IMF spelt out a series of structural reforms and policies that the Iraqi economy was required to achieve. The important reform that is relevant to this research is the requirement is for Iraq to develop mechanisms of action in terms of new fiscal and monetary policies and rearrange the accounts and audit according to international standards.

In 2005, the IMF offered Iraq another US\$475.4 million by way of Special Drawing Rights under a stand by arrangement (SBA). The program aims to achieve structural reforms and macroeconomic stability to help reduce Iraq's external deb.

The World Bank together with the IMF manages and controls the DFI. The World Bank is a major player in the restructuring of Iraq as it has funded 30 projects in Iraq relating to health, education and infrastructure. One of the key projects funded by World Bank is for Iraq to implement global standards for extractive industries, is the Extractive Industries Transparency Initiative (EITI). Iraq implemented the EITI in 2008-2012. Through this project on transparency the World Bank is influencing Iraq to change its accounting system in order to comply with EITI's disclosure requirements for extractive industries. Another key project funded by the World Bank relates to reform of Iraqi banking sectors. The aim is to support Iraq in the implementation of a new "Iraq Banking Reform Strategy" which took place during 2008-2012.

Since 2009, Iraq has invited IOCs to participate in oil bids for its major oil fields. Three major bids for oil and one bid for natural gas were for a 20-year contract on eight oil fields. There was a second bidding in 2010 for 11 newly discovered oil fields. The total reserves covered through these bidding rounds were more than 62 billion barrels for oil and 7.4 Tcf of natural gas in fourth bidding round. The successful IOCs in these major bids were Exxon Mobil, Shell, BP, Total, CNPC, ENI, and Gas prom, Statoil, LUKOIL, KOGAS JAPEX, TAPO and Iraqi oil companies [15]-[19]. These MNCs play a major role in Iraq's economy.

Big 4 accounting firms have played a significant role in the globalization of accounting by establishing bases worldwide [20]. Iraq is no different. From 2004, the Big 4 accounting firms started to open offices in Iraq.

\section{B. Current Accounting Practices in Iraq under Unified Accounting System (UAS)}

After the Arab Baath Socialist Party took control of Iraq in 1968 , it started to control the economy by following the Soviet and Egyptian social approaches at that time. In doing so, the Iraqi government in 1972 nationalized the private oil companies operating in Iraq which meant it had full control of the oil industry [2]. In order to control the operations of these companies, they classified them according to their type of activities for the purpose of placing them under state organized supervision, which was Iraq's National Oil Company (INOC). As a result, the Iraqi National Oil Company (INOC) had control of all Iraqi oil related industries through its different subsidiaries.

Having organized the state company operations at the ministerial level, the next step the government took was to streamline accounting requirements by introducing the Unified Accounting System (UAS) [2]. UAS was first implemented in the Ministry of Trade during 1969 and was made compulsory for its companies in 1972. The system requires double-entry accounting using a standardized format for preparing financial statements [2].

Another major milestone in April, 1979 was the setting up of a Central Committee of Accountants, which brought into place a system to cover all Iraqi sectors within three years using a national uniform accounting system [2]. As a result, in 1982 the Unified Accounting System was issued and become compulsory for Iraq's ministries and private sectors. The UAS is a tool for central economic planning, to achieve economic and social rationality, control and compliance to the economic system principles, and to ensure the optimum use of economic resources [2], [21]. The UAS uses a fund-based accrual methodology focused on accountability and stewardship [22]. While the UAS provides accounting 
laws, the Local Standards Committee specifies the detailed accounting methods and charts of account to be used in the different industries, including the extractive industry. According to the government's Central Committee, the UAS system provides information that can be used for planning, implementation and monitoring at every level of the economy; provides links between the economic units and the national accounts, which can be used to prepare the National Accounts, including Gross National Product and other statistical statements [21].

Under the UAS, there are nine main classes of accounts which are based on the accounts code of the Arab League. The first four classes, assets, liabilities, expenses and revenue, show the financial position and performance of the reporting unit. These classes are further divided into five or six sub-classes. Other classes are called control accounts dealing with cost accounting. They are designed to help the reporting units prepare reports including budgets for their activities according to the nature of their businesses [2], [21]. The IFRSs use elements, instead of classes and the elements are similar to classes 1 to 4 under UAS. Because the IFRSs relate to financial accounting, the other UAS classes are not covered in IFRSs.

Under the UAS the required financial statements are the Balance Sheet and the Income Statement (with an operations account used only for oil companies) with accompanying notes. The UAS also uses a total added value statement which the Ministry prepares for each sector (China and Russia are the other countries which use this Statement). The major difference from IFRSs is that under the UAS a cash flow statement is not required [2]. A Chart of Accounts is prepared consisting of the nine main account classes. The accounts classes reflect the classifications of financial and cost accounting transactions with a concentration on the previous period [2], [21].

Unlike IFRSs, the UAS standards value assets based on historical cost accounting. The cost of assets is defined as the "acquisition or manufacturing cost plus transportation, installation expenses and other expenses before using". The UAS uses methods of valuation and measurement which are not substantially different from those used in Western countries. Other than methods that reflect the central planning history, UAS requirements differ little from IFRSs standards. But this difference results in accounting treatments which differ between two systems. IFRSs standards are principles based in contrast to the rules based standards of UAS. There has been much debate on whether a rules based system is preferable to a principles based system. Iraq's accounting system is similar to that of the United States in that it is 'rules based' rather than the 'principles based system' of IFRSs. Rules relate to the objectives of the UAS. Complex rules, however, can lead to unnecessary difficulties in the preparation of financial statements [23].

\section{The Board of Supreme Audit (BSA)}

In 1968, the Iraqi government establishes the Board of Supreme Audit (BSA). The Board's main role was to use the UAS at the national level so as to provide pertinent accounting data and information to help in government control and planning [2]. The Chairman of the Board has direct links with the President (now the Prime Minister) of Iraq. The Board ensures all Iraqi public and private organizations adopt and follow UAS. However, to meet the needs of the international accounting environment the Iraqi legislative authorities established in 1995 a Local Standards Committee for developing local accounting standards [24]. The UAS is supported by a Local Standards Committee (with broad membership) which developed 14 accounting standards for Iraq. These standards are similar to the international accounting standards [24].

\section{LITERATURE REVIEW: WHY ADOPT IFRSS?}

\section{A. Opportunities for Adopting IFRSs}

The primary reason for adopting IFRSs is attributed to the growth of international trade, multinational firms, and foreign direct investments; the development and diversification of financial markets; the growth of global organizations like IMF, World Bank, OECD, and EU and similar developments [25]. According to [26], globalization of capital markets is an irreversible process in which there are benefits to be gained from mutually recognized and respected IFRSs. Using one set of financial statements cuts the costs for multinational firms of doing business across borders by reducing the need for supplementary information or reconciling financial statements that are prepared using national standards. They make information more comparable, thereby enhancing evaluation and analysis by users across the world [26]. [27] argues that a common set of practices will provide a "level playing field" for all companies worldwide but does not address who will bear the costs of harmonization or convergence. The decreased costs for multinationals, creditors and investors will not flow to the taxpayers and others in converging countries to offset the costs of education and retraining.

On a technical level, the prospect of greater mobility of capital at a decreased cost, more efficient allocation of resources, improved quality of financial reporting, a decline in earnings management [3], and avoidance of the necessity of having to develop their own accounting standards, against a backdrop of the accountability demands of the World Bank and IMF are all compelling incentives for the adoption of IFRSs by developing countries and emerging economies wishing to participate in global capital markets. The United Nations Conference on Trade and Development (UNCTAD) has acknowledged the need to "mobilize investment for financing economic and social development", and the essential role of a "global set of high-quality financial reporting standards" in that development [3]. [28] is of the view that the World Bank and IMF represent the most significant actors in promoting accounting harmonization within developing and emerging countries. While some researchers agree that implementation of IFRSs may support an increase in the quality of accounting information in developing and emerging economies and then attract foreign investments and resources to these countries, the IFRSs are not appropriate to the political, social and economic environment of these countries [29]-[33]. Despite this, many emerging economies and developing nations have adopted 
IFRSs, hoping to share in the benefits promised by such adoption.

\section{B. Challenges to Adopt IFRSs}

With change, there will always be obstacles; it is what one does with those obstacles that make all the difference [34]. In IFRS literature, there are many challenges and obstacles that have been highlighted with regard to the adoption of IFRSs. One obstacle lying in the path towards a set of international accounting standards that yield the promises made for them is "political" pressures that may be triggered by the Board's initiative to prescribe specific accounting treatments, eliminate alternative treatments, impose additional disclosure requirements, or tighten the allowed interpretations [35]. The political pressures consist of "self-interested" considerations or pleadings by preparers and others that may be detrimental to the interests of investors and other users, a phenomenon that has been associated with the term 'economic consequences' [35].

One of the important examples of the political pressure and "self- interested" are the lobbying of the IASB by the big oil companies to shape the IFRS 6 accounting standard was substantial and comprehensive [36]. The IASB's issue paper recommended that the successful efforts method be mandated for pre-production costs, a move which would eliminate the choice available between the full cost and successful efforts methods. In spite of the endorsement of this view by a majority $(78 \%)$ of the constituents who responded to the issues paper, the final outcome changed nothing, with choice being retained. The big petroleum companies successfully influenced the Board; the IASB was influenced by the very constituents it was supposed to regulate. The politics of the decision was obvious given the fact that the key players included ExxonMobil, PricewaterhouseCoopers (the audit firm of ExxonMobil), and the American Petroleum Institute [37].
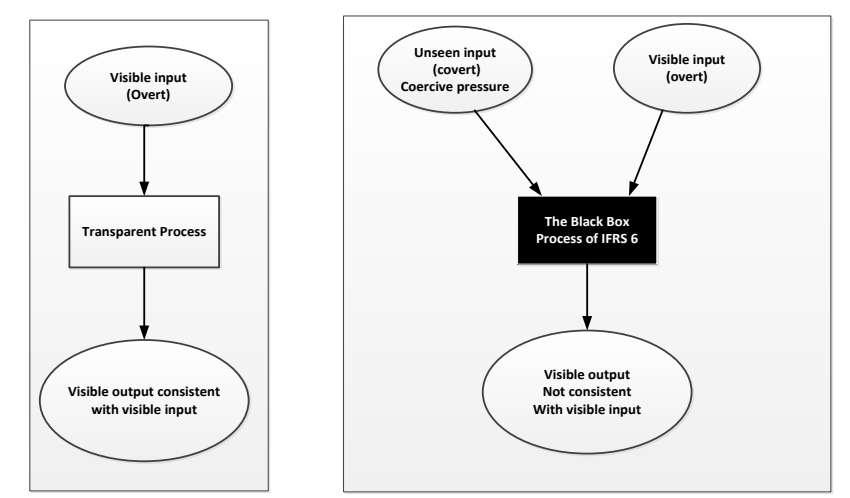

Fig. 1. The black box of the accounting standard sitting source: Adapted from Cortese and Irvine (2010).

Other obstacles to worldwide comparable financial statements by using international accounting standards were identified by [38]. Two factors are "comparability" through convergence and culture [38]. [34] added the obstacle of "Government," whereas others talked about culture and politics, which had been already covered by [38]. According to [39], differences between countries are due to culture which is a powerful environmental factor that affects the accounting system of a country as well as how individuals within that country perceive and use accounting information. Accountants' attitudes or value systems are related to and derived from societal values. Accounting values, in turn, affect accounting systems [39]. There are specifically three areas in which culture has been found to affect accounting standards: the reporting of financial information; auditors' perspectives and attitudes; and the system for management control [39]. Not only does culture affect accounting practices alone, but also affects politics which in turn will affect accounting practices [34].

Another example of the impact of culture for adopting international accounting standards, [40], studied the impact of culture on the harmonization of Russian Accounting Standards with the IFRSs by using semi-structured interviews with 53 Russian accountants. The analysis included the attitudes of the Russian accountants towards reporting under harmonized Russian Accounting Standards through comparing Soviet culture with Hofstede theory which advocates that history is more important than laws of nature in developing accounting practices. In addition, the review also includes [1], and [41] and [42] who established that differences between the two sets of accounting standards still exist. The study found that the Russian culture aspects such as uniformity, statutory control, secrecy, and conservatism are still preferences of the Russian accountants and impact on their behavioral and attitude. Further findings show accountants in Russia were reluctant to disclose financial reporting information for external users, preferring secrecy against transparency, as identified by Gray [40].

Another issue is Broken deadlines have reduced confidence in the IASB [43]. This suggests dysfunctional working processes and dysfunctional decision-making in the IASB. The board's inability to deliver its conceptual framework project was not the first time the IASB's credibility has been damaged by the duration of some of its projects [43]. [44] criticized the influence of the efforts to reunite both FASB and IASB to create one global accounting standards on the countries which already adopted IFRSs or which in their way to adopt IFRSs. He highlighted the differences between over complex "rules-based" approach, which is adopted by FASB (Iraqi UAS built on rules based system) and "principles based" which is followed by IASB [44]. [44] provided interesting conclusions for the countries that intend to harmonize or even these countries that already adopted or harmonized with IFRSs. He argues that these countries need to consider that many changes will happen in their regulation and law systems, and they will have to accept some accounting policies and procedures which are not in line with their interest. The accounting regulatory system in the US includes bureaucracy, and corporate lobbyists leading to complexity in US GAAP protocols, multiplicity of documents, and ponderous framework of interpretation and common law manner of complexity which are completely different for the ideology of IASB [44].

\section{External Pressures to Adopt International Accounting Standards}

The World Bank and the IMF are considered major players in world capital markets, as they are "deeply embedded in the structures of capitalism" [30]. These two organizations 
provide loans to certain countries to stimulate economic development, arguably from beneficial motives [45]. In doing so, the World Bank has pushed many countries to adopt international accounting standards or to redevelop their national standards based on them. In some cases, the bank makes the adoption of IFRSs as a requirement of their loans [11]. The World Bank and the IMF in many developing and emerging economies have used the Big 4 accounting firms to ensure adoption of IFRSs in those countries. As a result, these international accounting firms have played a significant role in the globalization of accounting by focusing on the establishment of international accounting standards in different areas around the world [20]. These firms have demonstrated that they are a powerful institutionalizing force as "international organizations which invest in systems of global coordination and control" [46].

Evidence of the role played by the professional accounting firms in countries is clear. For example, the adoption of IFRSs in Bangladesh was a response to the World Bank's requirement that any project financed by the bank be "certified by internationally reputable firms of accountants" [31]. The most conclusive evidence [33] is the case of Syria. Using interviews with Syrian professional accountants [33] studied the impact of globalization on the local accounting profession. They found that the Syrian profession faced competition from the Big 4 accounting firms which threatened local accounting and auditing jobs. In addition, the adoption and enforcement of IFRSs in Syria required extensive and expensive retraining of professionals [33].

\section{Methodology AND THEORETICAL FrAMEWORK}

In order to cover the complicated issues investigated, both primary and secondary data were collected for this study. The secondary data included the UAS (commonly known as "green book" in Iraq), agreements and documents of the World Bank and IMF related to Iraq, Big 4 accounting firm's reports in Iraq. Primary data was collected through 30 in-depth semi-structured interviews conducted with personnel from the management from the Board of Supreme Audit, members from Iraq's Local Standards Committee, Iraqi accounting professionals and academics, management in Iraqi oil companies and international oil companies operating in Iraq, management of international accounting firms operating in Iraq and representatives of the World Bank and IMF in Iraq.

The 30 interviews were conducted over a period of six months from February 2013 to November 2013 at Baghdad, Iraq. The interviews were undertaken personally and conducted in English and Arabic where needed, and 20 of the 30 interviews were recorded. Seven out for these 20 interviews recorded were in English and 13 were in Arabic. Five interviewees provided written answers, and the researcher took notes for the last five interviews as they did not give permission for recording. The researcher made notes both during the interview and immediately after each interview. Each interview lasted from a minimum of 30 minutes to a maximum of 90 minutes, with a mean of approximately 44 minutes, The 30 respondents comprised of managers (5), consultants (5), CFO (7), CAO (3), and academics (5), and professional (5) who have been involved both in the decision to transition and its possible implications for Iraq's accounting system to move to IFRSs by adopting, harmonizing or convergence. The transcripts of these interviews were coded for the main themes relating to opportunities and challenges for Iraq to move to IFRSs by using phenomenological approach.

Archival documents resources provide important support to the interviews. Analysis of the documents before the analysis of the interview data helped in understanding the background of the accounting system, providing information about factors impact the issue, especially the analysis of interview responses [47]. Archival resources examined included board minutes, formal documents of the Iraqi local accounting standards, post 2010 annual reports of Iraqi companies, the Iraqi UAS book, agreements and reports of World Bank and IMF, and the Big 4's reports about the Development Fund of Iraq after 2004. The qualitative content analysis is used to link the analysis of documents of this study with institutional theory [48].

Institutional theory and in particular new institutional theory (New Institutional Sociology NIS) and institutional isomorphism are used to explore the process of IFRS adoption in Iraq. In recent years, institutional theory has been attracted many researchers in the social sciences field. Further, in accounting literature many researchers have used new institutional theory and institutional isomorphism to explain accounting system between practices, institutions, routines, power and politics [31], [49]-[51]. In addition, many researchers such as [50], [52]-[54] have acknowledged the role of an institutional approach which has become a useful interpretation of accounting events.

This institutional approach constitutes institutional theory; it attends to the deeper and more resilient aspects of social structures. The theory considers the processes by which structures, including schemas, rules, norms, and routines become established as authoritative guidelines for social behavior. It inquiries into how these elements are created, diffused, adopted and adapted over space and time. In that respect, these elements can fall into decay and obsolescence [55]. Institutional theory focuses on the assumed values and beliefs of social and organizational life. Organizational conformity with these values and beliefs provides much more than technical benefits, bestowing powerful legitimizing attributes, thereby granting those organizations access to resources [6] and ensuring their survival in an increasingly organized and inter-connected society.

According to [6] the institutionalized field is defined as an established social order encompassing a set of rules and standardized practices. New institutional theory considers both social groups and organizations in relation to their environments, as well as the effects of external expectations on the group or organization and the development of structures and practices within the group as it seeks to establish its legitimacy. Institutionalization is a process whereby rules and practices in a particular social setting are developed and learnt. "Isomorphism" is the congruence between organizational arrangements and impinging (society-level) institutions which is explained through a process by which external institutions permeate internal 
structures and procedures [56]. Isomorphism has two components, namely competitive isomorphism which defines how competitive forces drive organizations towards adopting least-cost, efficient structures and practices although competitive forces are de-emphasized as a predominantly cultural and political activity. The second component, institutional isomorphism is broken down into three sub-categories [6]. The first of these is coercive isomorphism where impinging external factors such as government, policy, regulation, and or supplier relationships force an organization to adopt specific internal structures and procedures.

Formal coercive institutional pressures are the most obvious, since in an institutionalized environment there are elaborate rules and requirements including "pressures for conformity to public expectations and demands" [57]. Organizations gain and maintain legitimacy by conformity with these rules and regulations even if the changes made in response to those rules and regulations are more ceremonial than actual [6]. In a global setting, the theory hypothesizes that not only will nation states comply with international rules and regulations, but if they are desirous of competing in global capital markets, they will change isomorphically to adopt the regulatory systems deemed appropriate and desirable by other participants in that market [3].

The second sub-category is mimetic isomorphism whereby organizations emulate the internal structures and procedures adopted by other organizations because in situations of uncertainty, organizations modeled after other organizations in their field are perceived to be more legitimate and successful [6]. Nations (which can be thought of as organizations) do not need to stand out as being different, and they therefore, behave in ways that are socially acceptable. If many nations exhibit certain forms of behavior, the more pressure there will be on other nations to copy and follow that behavior especially in situations of uncertainty. Conversely, there is also the possibility that organizations or nations with a strong sense of identity and culture may resist pressure to copy other nations or organizations if they do not conform to that defined and understood identity.

In summary, the mimetic view stresses conformity with orthodox structures and identity particularly in times of uncertainty. Multinational corporations have established sophisticated systems of financial coordination of their subsidiaries [46]. In that sense, they have modeled to other organizations according to the desirability of global harmonization of certain activities such as financial reporting. The desire to mimic has been strong for developing and emerging economies, and as such, may explain their adoption of international accounting standards.

Normative isomorphism is the third sub-category of institutional isomorphism. It exists when organizations adopt the structures and procedures advocated by certain dominant professions, professional bodies and consultants. This typically "macro" focus has recently been criticized mainly because the theory requires greater integration with "micro" explanations and acknowledgement of the interactive nature of institutional processes. In accounting research institutional theory approaches offer a wide range of applicability for understanding the practice of accounting in organizations
[58], and by implication, for understanding the adoption of international accounting standards.

According to the above theoretical discussions, the following research questions were explored:

1) Which stakeholders influence Iraq's accounting system; what are the key factors pressuring Iraq to change from UAS to the IFRSs?

2) What opportunities and challenges to transitioning to IFRSs are identified in the literature?

3) What are the views of key personnel about these opportunities and challenges for Iraq?

Documents such as agreements and reports between Iraq and World Bank and IMF, MNCs, IOCs and Big 4 accounting firms are used to find out the relationships and the influence of these institutions on Iraq's accounting system.

\section{FINDINGS}

Analysis of documents of the key players which are affecting the Iraqi accounting system shows formal external coercive pressures on the accounting system in Iraq include the World Bank and IMF. Organizations use conformity with rules and regulations to gain and maintain legitimacy and to be acceptably organized from a legal point of view [6]. Conformity can be achieved in two ways: firstly, by ceremonially conforming to externally imposed regulations, and secondly, by actually internalizing the regulatory system. The IMF's Emergency Post Conflict Assistance (EPCA) and the Stand by Arrangement (SBA) agreements include terms of the accounting system in Iraq, terms which are tantamount to coercion. The terms of the EPCA agreement show that the IMF does not consider the current Iraqi accounting system suitable for the process of reform of the Iraqi economy. In addition, the IMF Country Report recommends that Iraq should organize its accounts and audit in accordance with international accounting and auditing standards.

The [59] states that Accountants in Iraq use the outdated Unified Accounting System, which includes standards that have not been updated since the mid-nineties and others which are about 70 years old (related to government accounting. An earlier [60] stated that Iraq needs to develop mechanisms of action of fiscal and monetary policies and the introduction of a lot of reforms in the Iraqi economy and rearrange the accounts and audit according to international standards. The reports do not include any analysis as to why the UAS is unsuitable for Iraq. Yet the pressure to adopt IFRSs is evident as stated in the IMF's country report:

In an effort to regularize the financial relations between the government and the CBI, the ministry of finance and the CBI are in the process of agreeing to restructure all government obligations held by the central bank. This agreement will be implemented in installments to facilitate the payments by the government, while minimizing any possible negative impact on the capital of the CBI, taking into consideration acceptable international accounting standards [60].

Institutional theory posits that organizations seek homogeneity which in this situation is the adoption of international accounting standards in order for Iraq to gain legitimacy in the accounting world. The World Bank and the 
IMF, major players in world capital markets, are "deeply embedded in the structures of capitalism" [30]. Their advocacy of a market economy for Iraq is in line with the IMF's view that IFRSs economies should be based on capitalism and that no other accounting system can support a market economy. By linking financial support to Iraq with the adoption of IFRSs, the IMF and the World Bank are coercing Iraq to adopt IFRSs. After four years of the World Bank's banking sectors reform project, the BSA agreed the Central Bank of Iraq will only prepare financial statements according to IFRSs on an experimentally basis.

In its report on the disbursements in Iraqi ministries, to the Iraqi government and the IMF, KPMG stated its difficulties to understand Iraq's UAS. Further in its report, KPMG recommended that Iraq should adopt international standards of accounting and auditing, because KPMG was unable to express any assurance on disbursements as Iraq did not follow the IFRS; or international standards on Auditing [61]. Surely a firm as international as KPMG possesses the expertise to understand an accounting system that differs from IFRSs. It is apparent that KPMG is indirectly influencing the need for Iraq to adopt international new standards.

EY in its project report on the Development Fund for Iraq recommended Iraq to adopt policies and procedures in accordance with the American Institute of Internal Audit standards [62]. It appears that the key objective was to bring about similarity with their counterparts in other organizations [6]. In its report on Development Fund for Iraq, 2011 (three years after EY's report on the same project) PwC stated that firms in Iraq still used same procedures, same partnerships, and same notes. PwC recommended Iraqi government to follow pervious recommendations of EY (in 2008) and KPMG (in 2005) that Iraq should continue to take concrete steps to implement and follow up on the previous audit findings and recommendations, including improving financial reporting and control systems over oil export sales and key Iraqi ministries, as well as ensure completeness of Iraq's oil export accounts [10]. The work and reports of the Big 4 public accounting firms relating to Iraq show the application of normative isomorphism (as defined by [6]) in Iraq.

The interviews focused on oil and gas sector, because this sector provides around 95\% of Iraq's GDP and most international companies are currently operating in Iraq are represented by IOCs. The analysis of those interviews focused on five themes from which the key issues for this study are drawn. All respondents agreed that the current UAS is different in comparison with international standards for accounting for oil and gas. Further they opined that there is also a need to modify UAS for other sectors in Iraq to be in line with IFRSs. Many reasons were proffered such as, the UAS system is old and was primarily designed to serve central government; it does not cover specifically the oil and gas industry, and the main purpose of measurements and disclosures are only for the central government and not for any other stakeholder. Despite these views, the respondents agreed that the BSA cannot force UAS on MNCs and IOCs operating in Iraq, though they are of the view that that Iraq needs the IOCs and MNCs in the rebuilding of the oil and gas sector and other sectors after more than thirty years of wars and sanctions.

Another view was that the UAS is a local standard which falls short when compared with international standards for IOCs and MNCs and to supplement this BSA has been allowing IOCs to prepare two reports for tax purposes, one for their home country and one for the host country Iraq. The case of IOCs influence over Iraq shows the perspective of mimetic isomorphism. These companies have experienced staff and advanced technology and hence are able to influence Iraq to modify its economic, legal and financial legislation. [6] comments are relevant:

When organizational technologies are poorly understood (March and Olsen, 1976), when goals are ambiguous, or when the environment creates symbolic uncertainty, organizations may model themselves on other organizations [6].

Many interviewees are of the view that Iraqi oil companies should take advantage and work with IOCs, by adopting or adapting the structure and procedures of these companies because Iraqi economy completely destroyed, so Iraq needs all available experiences from international companies and global organizations in different aspects. This is a reflection of [3] and consistent with the view of [6]:

The global harmonization requires linked with regulatory regimes of the dominant nation state. The desirability has been reinforced for developing and emerging economies of conformity and convergence with practices both of multinational corporations and nations trading partners [3].

Around half of the respondents suggested that any training created by a change to IFRSs should be done by a 'special committee' formed by the BSA which is responsible for accounting policies and procedures in Iraq. Another view (four respondents from the Big 4 accounting firms and Iraqi academics) is that the training on IFRSs should be done by BSA only, because this organization has a big budget and has been given the authority from the government. Iraqi academics and some other respondents are of the view that the training should be the responsibility of the Big 4 accounting firms as they have experienced and qualified staff in the IFRSs. After a short period in Iraq, these Big 4 firms are in a position to impose their style on the accounting and auditing environment in Iraq. This is evidence of normative isomorphism as [63] attributed the growth of a large professionally trained labor force as the most striking demonstration of normative institutional pressures.

As to the opportunities and benefits of adopting the IFRSs in Iraq the respondents' answers reflect mimetic isomorphism as they are of the view that the Iraqi oil companies will be best developed by stimulating the same organizational structure and procedures used in the IOCs and MNCs. In 2007 the Iraqi government issued a draft for a new law for oil and gas industries, to replace the oil and gas law of 1961. The Iraqi legislators issued this law to allow IOCs to invest in Iraqi oil and gas fields and to help this sector to overcome barriers that it had to face in the past. The IOCs have a global trading system which was designed to capture investment, for example, the rush of petrodollars from the third international oil boom in recent times. These global trading systems have been identified as important in the 
diffusion of globally acceptable practices.

Obstacles to the adoption of IFRSs were identified: resistance to change, transition period, responsibility of training staff personal, and the need to break out of the routine and organizational structure under the old legislation in Iraqi oil companies as well as other industrial sectors. The "resisting change" was discussed as the most important challenge by respondents, and all respondents agreed that the main obstacle will be the old staff of the BSA. One of the strong views on the challenge of moving from "routine and organizational structure with old legislation in Iraqi oil companies and other Iraqi companies" to a new system is that it is a form of coercive pressure by the World Bank on the Iraqi Central Bank although that coercive pressure has gained little as pointed out by a senior manager in KPMG: The routine, for example, there is a memo was issued from Central Bank to Iraqi local banks in 2011. This memo asked local banks to prepare their financial statements according to IFRSs, but until now, both Central Bank and local bank still use UAS.

The current situation in Iraq is an example of Institutional isomorphism, more specifically coercive isomorphism by the World Bank and IMF; mimetic isomorphism by the IOCs and normative isomorphism by the Big 4 accounting firms in Iraq.

Most respondents thought that the UAS should be changed. They support their opinion by stating Iraq is moving to a market economy, while the UAS is designed for a social or central planned economy. UAS does not cover oil and gas industry specifically, and the Iraqi local Standards also do not cover all IFRSs and IFRSs. This is not a very difficult issue, given the fact that the UAS and the local standards can be easily modified. The "move to market economy" will be difficult for Iraq, even though it is pressurized by external institutions which have been at work on the Iraqi government since 2003, via agreements such as the agreement with the UN, IMF and World Bank - showing the other side of coercive pressure, which is capitalism. Some respondents are against Iraq's change from its UAS to IFRSs. Of these eight respondents, five are members of the BSA. Their view is that Iraq should continue with its UAS because the UAS as a system has worked for more than 30 years without any major issues or problems, the process of changing to the IFRSs requires many factors such as a long transition period, changed manual and electronic systems which need support from IT infrastructure, changed University curriculum and training, and the current situation in Iraq makes doing this project difficult, if not impossible.

\section{CONCLUSION}

The current situation in Iraq is an example of Institutional isomorphism, more specifically coercive isomorphism by the World Bank and IMF; mimetic isomorphism by the MNCs IOCs and normative isomorphism by the Big 4 accounting firms in Iraq. The accounting system in Iraq (UAS) is currently facing coercive pressure from external institutions, represented in the World Bank and IMF. The World Bank is pressuring Iraq in the banking sector and the IMF is on Iraq's financial policy. Consequently, both the World Bank and
IMF have used terms like 'transparency' and 'disclosure' to force the change particularly in oil and gas sector to adopt the IFRSs.

As evidenced in the past, IOCs also used pressure to ensure Iraq adopted a new oil and gas law in 2007 that permitted them to invest in Iraq's oil and gas fields. IOCs continue to use their pressure to get more investment opportunities in Iraq. In 2011 and 2012 four joint ventures by the IOCs with Iraqi government were established. These four joint ventures makes accounting more complicated as to which standards the joint ventures should follow - the UAS or the IFRSs Managers in Iraqi oil companies and academics) mentioned that the Iraqi oil companies could be mimetic with procedures of the IOCs as IOCs have developed technology, management structure and experience staff.

The role that the Big 4 accounting firms play in Iraq which appears to be a normative pressure to push countries to adopt IFRSs. In Iraq, these firms do not have separate pressures to adopt IASs, but they help IOCs to prepare reports according to UAS for Tax purposes. Further, its work in Iraq depends on World Bank and IMF, In fact, these firms like a tool used by World Bank and IMF to achieve their objectives in Iraq.

The BSA yet maintains a strong position in Iraq and uses it internal and formal institutional pressure to keep UAS. It is a fact that the UAS does not cover oil and gas industry specifically, because it designed in 1980s and at that time, there was no IASs or IFRSs. The UAS is still working without update. The weaknesses in UAS regarding the extractive industries are a reflection of the accounting treatments globally for these industries. Even IFRS 6 does not cover all the specifics of this industry while giving great freedom to the economic units in the choice of accounting treatments, which make the financial comparison and evaluation in this industry more difficult and complex.

While institutions such as World Bank, IMF and WTO are ensuring that developing and emerging economies adopt IFRSs in order to become a part of "Globalization" to bring more opportunities and benefits to their countries, there is no mention about the benefits obtained by each of these institutions and developed countries in this process of globalization. "Globalization" in the case of Iraq translates into opening the economy's doors to MNCs and IOCs (from developed countries) to work in Iraq. In doing so, these institutions have worked to change oil and gas laws in Iraq to allow them further investments in Iraq. The literature shows the role of Big 4 accounting firms in pushing countries to adopt IFRSs in order to achieve uniform accounting standards globally. In the case of Iraq, there is no role for these firms, but this study gives evidence about a strong relationship between these firms and imperialist institutions operating in Iraq.

\section{REFERENCES}

[1] S. J. Gray, "Towards a theory of cultural influence on the development of accounting systems internationally," ABACUS, vol. 24, no. 1, pp 1-15, 1988.

[2] F. K. Al Najjjar, "Accounting in Iraq Babylon: A historical perspective,” Oil, Gas\& Energy Quarterly, vol. 58, pp. 125-140, 2009.

[3] H. Irvine, "The global institutionalization of financial reporting: The case of the United Arab Emirates," Accounting Forum, vol. 32, pp. 125-142, 2008. 
[4] S. Sunder, "IFRS monopoly: The pied piper of financial reporting," Accounting and Business Research, vol. 41, no. 3, pp. 291-306, 2011.

[5] K. R. Larson and L. D. Street, "Convergence with IFRS in an expanding Europe: Progress and obstacles identified by large accounting firms, survey," Journal of International Accounting, Auditing and Taxation, vol. 13, pp. 89-11, 2004.

[6] P. J. DiMaggio and W. Powell, "The iron cage revisited: Institutional isomorphism and collective rationality in organizational fields," American, Sociological Review, vol. 48, pp. 147-160, 1983.

[7] R. Frei, "Extracting oil from Turmoil: The Iraqi oil industry and its role as a promising future player in the global energy market," Hein Online---4 Rich. J. Global L. Bus, 2004.

[8] Energy Information Administration (EIA). (2004). Country Analysis Brief, Iraq. [Online]. Available: http://www.eia.doe.gov/cabs/iraq.htm

[9] E. Diehi. (2008). IMF Helps Monitor Iraq Oil Money. [Online]. Available: http://www.Imf.org/external/pubs/ft/survy/so/2008/INT030708A.htm

[10] IAMB Press Release. (June 30, 2011). International Advisory and Monitoring Board (IAMB) of the Development Fund for Iraq. [Online]. Available:

http://www.iamb.info?pdf/IAMB\%2030\%202011\%20press\%20releas e.pdf

[11] K. Alfredson, K. P. Leo, R. P. Pacter, and J. Radford, Applying International Accounting Standards, Milton, Queensland: John Wiley\& Sons Australia, Ltd, 2005, ch. 1, pp. 1-1102.

[12] Iraq Ministry of Finance. (2007). Iraq and Paris Club debts. [Online]. Available: http://www.mof.gov

[13] International Monetary Fund (IMF), "First and second reviews under the stand-by arrangement," IMF Country Report 06/301, August, 2006.

[14] A. Shakir, "The policies of economic reforms in the developing countries with special emphasis on Iraq," Ministry of Planning, 2007.

[15] Energy Information Administration (EIA). (2013). Country Analysis Brief, Iraq. [Online]. Available: http://www.eia.doe.gov/cabs/iraq.html

[16] Energy Information Administration (EIA). (2010). Country Analysis $\begin{array}{llll}\text { Brief, Iraq. } & \text { [Online]. }\end{array}$ http://www.eia.doe.gov/cabs/iraq.html

[17] M. C. Blanchard. (2008). Iraq: Oil and gas legislation, revenue sharing, and U.S. Policy. CRS report for congress. [Online]. Available: http://www.crs.gov

[18] Iraq Ministry of Oil. (2011). Gas fields investments. [Online]. Available: http:// www.oil. Gov.iq

[19] Financial Times. Iraq signs $\$ 17 \mathrm{bn}$ gas deal with Shell and Mitsubishi. (November 27, 2011). [Online]. Available: http://www.ft.com/intl/cms/0/ba07dl54-192b-11el-92d8-00144feabdc $0 . \mathrm{html}$

[20] H. B. Perera, A. R. Rahman, and S. R. Cahan, "Globalisation and the major accounting firms," Australian Accounting Review, vol. 13, no. 1, pp. 27-37, 2003.

[21] Board of Supreme Audit (BSA), Unified Accounting System (UAS), the Republic of Iraq, 1987.

[22] S. Peng and J. V. Smith, "Chinese GAAP and IFRS: An analysis of the convergence process," Journal of International Accounting Auditing and Taxation, vol. 19, pp. 16-34, 2010.

[23] R. T. Shortridage and M. Mark. (2004). Defining Principles-Based Accounting Standard. [Online]. Available: http://www.nysscpa.org Print versions /cpaj /2004/p34.htm

[24] Board of Supreme Audit (BSA). (2010). The Board of Accounting and Auditing Standards. [Online]. Available: http://www.bsairaq.net

[25] A. Ahmet and A. Rafet, "First time application of IFRs and its impact on financial ratios: A study on Turkish listed firms," Problems and Perspectives in Management, vol. 5, no. 2, pp. 99-112, 2007.

[26] A. Madawaki, "Adoption of international financial reporting standards in developing countries: The case of Nigeria," International Journal of Business and Management, vol. 7, no. 3, pp. 152-161, 2012.

[27] L. S. Murphy, "Are international financial reporting standards (IFRS) an unstoppable juggernaut for US and global financial reporting?" The Business Review, Cambridge, vol. 10, no. 1, pp. 25-31, 2008.

[28] T. E. Cooke and R. S. Wallace, "Financial disclosure regulation and its environment: a review and further analysis," Journal of Accounting and Public Policy, vol. 9, pp. 79-110, 1990.

[29] E. E. Chamisa, "The relevance and observance of the IASC standards in developing countries and the particular case of Zimbabwe," The International Journal of Accounting, vol. 35, no. 2, pp. 267-86, 2000.

[30] M. Annisette, "The true nature of the World Bank," Critical Perspective in Accounting, vol. 15, pp. 303-323, 2004.

[31] M. Z. Mir and A. S. Rahaman, "The adoption of international accounting standards in Bangladesh," Accounting, Auditing \& Accountability Journal, vol. 18, no. 6, pp. 816-841, 2005.
[32] S. Askary, S. P. James, and H. Yazdifar, "Influence of culture on accounting uniformity among Arabic nations, education," Business and Society: Contemporary Middle Eastern Issues, vol. 1, no. 2, pp. 145-154, 2008.

[33] S. Gallhofer, J. Haslam, and R. Kamla, "The accountancy profession and the ambiguities of globalization in a post-colonial, Middle Eastern and Islamic context: Perceptions of accountants in Syria," Critical Perspectives on Accounting, vol. 22, 2011.

[34] B. Theodore, "An analysis of the obstacles of culture, government, and lack of support for international accounting standards," A Senior Thesis Submitted in Partial Fulfilment of The Requirements for Graduation in the Honors Program, Liberty University, 2007.

[35] S. A. Zeff, "'Political' Lobbying on Proposed Standards: A Challenge to the 1ASB," American Accounting Association, Accounting Horizons, vol. 16, no. 1, pp. 43-54, 2002.

[36] C. L. Cortese and H. J. Irvine, "Investigating international accounting standard setting: The black box of IFRS 6," Research in Accounting Regulation, vol. 22, no. 2, pp. 87-95, 2010.

[37] C. L. Cortese, H. J. Irvine, and M. A. Kaidonis, "Powerful players: How constituents captured the setting of IFRS 6, an accounting standard for the extractive industries," Accounting Forum, vol. 34, pp. 76-88, 2010.

[38] S. A. Zeff, "Some obstacles to global financial reporting comparability and convergence at a high level of quality," The British Accounting Review, vol. 39, pp. 290-300, 2007.

[39] T. S. Doupnik and G. T. Tsakumis, "A critical review of tests of Gray's Theory of culture relevance," Journal of Accounting Literature, vol. 23, pp. 1-48, 2004.

[40] A. Combs, M. Samy, Martin, and A. Myachina, "Cultural impact on the harmonization of Russian Accounting Standards with the International Financial Reporting Standards. A practitioner's perspective," Journal of Accounting Andizational Change, vol. 9, no. 1, pp. 26-49, 2013.

[41] C. W. Nobes. (2001). GAAP 2001 - A Survey of National Accounting Rules Benchmarked Against International Accounting Standards IFAD. [Online]. Available: http://www.iasplus.com/en/resources

[42] C. W. Nobes, "The survival of international differences under IFRS towards a research agenda," Accounting and Business Research, vol. 36, no. 3, pp. 233-245, 2006.

[43] R. Crump, "Hoogervorst gets tough over IASB framework deadline," Accountancy, pp. 1-2, 21 October, 2012.

[44] S. Haswell, "Over-complexity in accounting standards and the emerging duopoly of us and IFRS," Australian Accounting Review, vol. 16, no. 2, pp. 49-59, 2006.

[45] D. Neu, G. E. Ocampo, G. P. D. Omar, and F. Z. Margarita, "Facilitating' globalization processes: Financial technologies and the World Bank," Accounting Forum, vol. 26, pp. 271-290, 2002.

[46] D. Cooper, J. Greenwood, R. B. Hinings, and J. L. Brown, "Globalization and nationalism in a multinational accounting firm: The case of opening new markets in Eastern Europe," Accounting Organization and Society, vol. 23, no. 5/6, pp. 531-548, 1998.

[47] N. Kondracki, Nancy, N. Wellman, and D. R. Amundson, "Content Analysis: Review of Methods and their application in Nutrition Education," Journal of Nutrition Education and Behavior, vol. 34, no. 4, pp. 224-23, 2002.

[48] J. Moll, M. Major, and Z. Hoque, "The qualitative Research tradition," Methodological Issues in accounting research: Theories and Methods, Spiramus Press Ltd London SEI, ch. 18, pp. 375-398, 2006.

[49] J. Burns, "The dynamics of accounting change inter-play between new practices, routines, institutions, power and politics," Accounting. Auditing \& Accountability Journal, vol. 13, no. 5, pp. 566-596, 2000.

[50] J. F. Dillard, J. T. Rigsby, and C. Goodman, "The making and remaking of organization context, Duality and the institutionalization process," Accounting, Auditing \& Accountability Journal, vol. 174, pp. 506-542, 2004.

[51] F. P. Pope and J. S. Mcleay, "The European IFRS experiment: objectives, Research Challenges and some early evidence," Accounting and Business Research, vol. 41, no. 3, pp. 233-26, 2011.

[52] V. L. Carpenter and E. H. Feroz, "GAAP as a symbol of legitimacy: New York State's decision to adopt generally accepted accounting principles," Accounting Organizations and Society, vol. 17, no. 7, pp. 613-643.

[53] M. A. Covaleski and M. W. Dirsmith, "The preservation and use of public resources: Transforming the immoral into the merely factual," Accounting Organizations and Society, vol. 20, no. 2/3, pp. 147-173, and 1995 .

[54] M. Hussain and Z. Hoque, "Understanding non-financial performance measurement practices in Japanese banks: A new institutional 
perspective," Accounting, and Accountability Journal, vol. 15, no. 2 pp. 162-183, 2002.

[55] W. R. Scott, "Institutional theory: Contributing to theoretical research program," Great Minds in Management: The Process of Theory Development, K. G. Smith and M. A. Hitt, Eds. Oxford UK: Oxford University Press Publications, 2004, pp. 1-47.

[56] J. Moll, J. Burns, and M. Major, Institutional Theory, Methodological Issues in Accounting Research: Theories and Methods, Spiramus Press Ltd London, SE1, 2006, ch. 10, pp. 183-205.

[57] C. Oliver. "The influence of institutional and task environment relationships on organizational performance: The Canadian construction industry," Journal of Management Studies, vol. 34, no. 1, pp. 99-124, 1997.

[58] W. R. Scott, Institutional and Organization, 2nd ed., Sage Publishing, London: 2001, ch. 1, pp. 1-251.

[59] World Bank. (2012). Republic of Iraq, World Bank report about: Financial Sector review. [Online]. pp. 1-273. Available: http://www.WorldBankSite.

[60] International Monetary Fund (IMF), "Stand-by arrangement," IMF Country Report, no. 04/325, September 2004.

[61] KPMG. (2005). Development Fund for Iraq. [Online]. Available: http://www.FINDLAW.com

[62] Ernst and Young (EY). (2008). Development Fund for Iraq. [Online]. Available: http://www.E\& Y .com

[63] W. R. Scott, Institutions and Organizations, Thousand Oaks, CA: Sage, 1995, pp. 1-178.

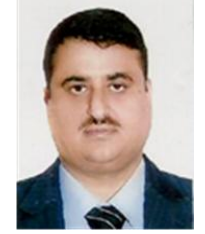

Mohammed Abud-Allah Ibrahim is a final year's PhD candidate in accounting at the University of Newcastle. He originally came from Iraq and was a lecturer at the University of Baghdad. He has got the B.Sc. degree in accounting from Baghdad University, Iraq and master degree in accounting from University of Baghdad. $\mathrm{He}$ also did master degree on "Job Order Costing System and its Role in Performance Evaluation of Responsibility Centers." He also holds a diploma in graduate certificate in business research (GSBR) in 2010 from Newcastle University. He has around 21 years' experience in accounting practice in Iraq. He also has some journal publications in Iraq and Jordan. He worked with Ernest \& Young (Baghdad office). He is also a visitor lecturer at Ahgaff University /Yemen.

Patricia Stanton is the principal supervisor, who has supervised many $\mathrm{PhD}$ students to completion. She has published in international journals mainly in accounting related areas.

DMarcus Rodrigs is a co-supervisor and has worked in one of the Big 4 public accounting firms, undertaken consultancy work for government institutions, and listed companies in the field of accounting. 